PAPER • OPEN ACCESS

Lecturers' Understanding on Indexing Databases of SINTA, DOAJ, Google Scholar, SCOPUS, and Web of Science: A Study of Indonesians

To cite this article: Ansari Saleh Ahmar et al2018 J. Phys.: Conf. Ser. 954012026

View the article online for updates and enhancements. 


\section{Lecturers' Understanding on Indexing Databases of SINTA, DOAJ, Google Scholar, SCOPUS, and Web of Science: A Study of Indonesians}

Ansari Saleh Ahmar ${ }^{1,235}$, Nuning Kurniasih ${ }^{2}$, Dasapta Erwin Irawan ${ }^{3}$, Dian Utami Sutiksno $^{4}$, Darmawan Napitupulu ${ }^{5}$, Harapin Hafid ${ }^{6}$, Muhammad Ikhsan Setiawan $^{7}$, Janner Simarmata ${ }^{8}$, Agung Wibowo', Ahmad Sururi ${ }^{10}$, Akbar Iskandar $^{11}$, Andre Paulus Saleky ${ }^{12}$, Citra Kurniawan ${ }^{13}$, Danner Sagala ${ }^{14}$, Dewiana Novitasari ${ }^{15}$, Dian Eka Indriani ${ }^{16}$, Early Ridho Kismawadi ${ }^{17}$, Ende ${ }^{18}$, Fabian Souisa ${ }^{19}$, Febri Liantoni ${ }^{20}$, Fitridawati Soehardi ${ }^{21}$, Hardi ${ }^{21}$, Haries Pribady $^{22}$, Hasan Baharun ${ }^{23}$, Heny Vensye Saiya ${ }^{24}$, Indrya Mulyaningsih ${ }^{25}$, Irfana Diah Faryuni ${ }^{26}$, Irwan Sugiarto ${ }^{27}$, Joko Sampurno ${ }^{26}$, Lusi Dwi Putri ${ }^{21}$, Muh. Barid Nizarudin Wajdi ${ }^{28}$, Muhammad Syahrul Kahar ${ }^{29}$, Muthia Anggraini ${ }^{21}$, Novia Nur Rosyida ${ }^{30}$, Otto Fajarianto ${ }^{31}$, Ratnadewi ${ }^{32}$, Riski Amalia Madi ${ }^{6}$, Ruzita Sumiati $^{33}$, Saeful Bahri ${ }^{34}$, Tomi Listiawan ${ }^{35}$, Uun Dwi Al Muddatstsir ${ }^{17}$, Vivi Aulia $^{36}$, Wahyu Widyantoro ${ }^{37}$, Wan Anita ${ }^{38}$, Wellem A. Teniwut ${ }^{19}$, A.A Gde Satia Utama $^{39}$, Aan Aswari ${ }^{40}$, Abd. Ghofur ${ }^{41}$, Abdul Atsar ${ }^{42}$, Abdul Haris Nasution ${ }^{43}$, Abdul Rahman Suleman ${ }^{44}$ Abdurrozzaq Hasibuan ${ }^{43}$, Achmad Daengs GS ${ }^{45}$, Achmad Yusuf ${ }^{46}$, Adi Santoso ${ }^{47}$, Agung Nugroho Catur Saputro ${ }^{48}$, Agus Darmuki $^{49}$, Agustinus Suradi ${ }^{50}$, Ahmad Al Yakin ${ }^{51}$, Ainur Rifqi ${ }^{23}$, Aji Raditya ${ }^{52}$, Albertoes Pramoekti Narendra ${ }^{53}$, Amaliatulwalidain ${ }^{54}$, Ambo Upe ${ }^{6}$, Andi Riyanto $^{55}$, Andik Wijayanto ${ }^{56}$, Andri Yanto ${ }^{2}$, Angra Meta Ruswana ${ }^{57}$, Anita Dewi Moelyaningrum $^{58}$, Anna Yuliana ${ }^{3}$, Anto Ariyanto ${ }^{21}$, Ardiansah ${ }^{21}$, Ari Purwadi ${ }^{59}$, Aria Hendrawan ${ }^{60}$, Aria Wahyuni ${ }^{61}$, Arjulayana ${ }^{52}$, Arlis Dewi ${ }^{62}$, As'adi ${ }^{63}$, Asep Najmurrokhman $^{64}$, Asih Niati ${ }^{60}$, Asrianti ${ }^{6}$, Bahidin Laode $\mathbf{M}^{65}$, Bambang Eko Hari Cahyono ${ }^{66}$, Bayu Adhi Prakosa ${ }^{67}$, Beta Ubaya Nindya ${ }^{68}$, Budianto Hamuddin $^{21}$ Cahya Fajar Budi Hartanto ${ }^{69}$, Castaka Agus Sugianto ${ }^{70}$, Chairuddin $^{16}$, Cut Sriyanti ${ }^{71}$, D. Purnomo ${ }^{72}$, Dahlena Sari Marbun ${ }^{43}$, Dahlia Andayani $^{73}$, Daniel Susilo ${ }^{74}$, Darmawan ${ }^{75}$, Desi Ulpa Anggraini ${ }^{76}$, Dhanar Intan Surya Saputra ${ }^{77}$, Dian Febrida Sari $^{78}$, Dian Rianita ${ }^{21}$, Diana Arief ${ }^{6}$, Didi Susanto $^{79}$, Didin Hadi Saputra ${ }^{73}$, Didit Darmawan ${ }^{80}$, Dini Afriansyah ${ }^{81}$, Djohar Maknun $^{25}$, Djufri Rays Pattilouw ${ }^{82}$, Dwi Cahyono ${ }^{83}$, Dwi Ermayanti ${ }^{84}$, E. Wityasminingsih $^{85}$, Eka Hartati ${ }^{86}$, Eka Maya Sari Siswi Ciptaningsih ${ }^{87}$, Ekbal Santoso $^{88}$, Eko Sumartono ${ }^{89}$, Elfrida Ratnawati ${ }^{90}$, Elida Gultom ${ }^{91}$, Emah Khuzaemah $^{25}$, Emilia Dewiwati Pelipa ${ }^{92}$, Endah Masrunik $^{93}$, Endang Fourianalistyawati $^{{ }^{4}}$, Eni Defitriani ${ }^{95}$, Erfan Yudianto ${ }^{96}$, Eric Kunto Aribowo ${ }^{50}$, Erpidawati $^{97}$, Erwinsyah Satria ${ }^{98}$, Ety Youhanita ${ }^{41}$, Euis Erlin ${ }^{57}$, Evi Gravitiani ${ }^{48}$, Evi Sukmayeti $^{99}$, Fadlina ${ }^{100}$, Fathimah ${ }^{30}$, Fatimah $^{51}$, Fatimah Nur Arifah ${ }^{101}$, Fauzi Farchan $^{102}$, Febrianty ${ }^{103}$, Fedianty Augustinah ${ }^{83}$, Feri Huda ${ }^{88}$, Fidrayani ${ }^{104}$, Firman $^{105}$, Folkes E. Laumal ${ }^{106}$, Gumgum Gumelar ${ }^{107}$, Gunawan Ali $^{108}$, Hadi Arnowo ${ }^{109}$, Haida Dafitri ${ }^{110}$, Halifia Hendri ${ }^{111}$, Hani Tuasikal ${ }^{112}$, Hardianto Djanggih $^{113}$, Harry Dhika ${ }^{114}$, Heri Prabowo ${ }^{115}$, Herlina Ahmad ${ }^{51}$, Himmatul 
Ulya $^{116}$, Ifit Novita Sari ${ }^{117}$, Ilham Khairi Siregar ${ }^{118}$, Indra Gunawan Pratama ${ }^{119}$, Indriyani $^{120}$, Irfan Sudahri Damanik ${ }^{121}$, Irma Setyawati ${ }^{122}$, Irwan Bempah ${ }^{123}$, Irwan Setyowidodo ${ }^{124}$, Isma Coryanata ${ }^{89}$, Itsar Bolo Rangka ${ }^{114}$, Jef Rudiantho Saragih $^{125}$, Joyce Christian Kumaat ${ }^{126}$, Jubilezer Sihite ${ }^{127}$, Junita Sipahelut ${ }^{128}$, Kadeni $^{88}$, Kamid ${ }^{129}$, Ketut Sukiyono ${ }^{89}$, Khairul Imtihan ${ }^{130}$, Khuriyatul Husna ${ }^{21}$, Kiky Nurfitri Sari ${ }^{131}$, Kurniawan ${ }^{21}$, La Ili ${ }^{6}$, La Ode Asmin ${ }^{132}$, La Ode Husen ${ }^{40}$, Lala Nailah Zamnah ${ }^{57}$, Lina Fitriani ${ }^{133}$, Listian Indriyani Achmad ${ }^{134}$, Lutfiyah Dwi Setia $^{135}$, M Chairul Basrun Umanailo ${ }^{136}$, M. Ali Ghufron ${ }^{49}$, Maria Purnama Nduru $^{137}$, Marsahip ${ }^{138}$, Martina Napratilora ${ }^{139}$, Maulana Yusuf Aditya ${ }^{16}$, Meri Andriani $^{140}$, Merla Madjid ${ }^{141}$, Mira Aliza Rachmawati ${ }^{142}$, Mita Rosaliza ${ }^{143}$, Moh. Affaf $^{16}$, Mohammad Rizki Fadhil Pratama ${ }^{144}$, Mufida Khairani ${ }^{145}$, Mufria $J$ Purba $^{146}$, Muh. Ardian Kurniawan ${ }^{147}$, Muh. Shofi ${ }^{148}$, Muhamad Ratodi ${ }^{149}$, Muhamad Yamin Noch ${ }^{150}$, Muhammad Affan Ramadhana ${ }^{151}$, Muhammad Alif ${ }^{152}$, Muhammad Fajri ${ }^{107}$, Muhammad Fuad ${ }^{140}$, Muhammad Irfan Nasution ${ }^{118}$, Muhammad Khoiruddin Harahap ${ }^{153}$, Muhammad Luthfi $\mathbf{H}^{154}$, Muhammad Sholahuddin $^{154}$, Murjainah ${ }^{155}$, Mursyid ${ }^{40}$, Mustafa ${ }^{156}$, Musthafa Akbar ${ }^{143}$, Mustofa Abi Hamid ${ }^{157}$, Muthmainnah ${ }^{51}$, Nancy Nopeline ${ }^{127}$, Nani Hartati ${ }^{158}$, Nanik Setyowati $^{89}$, Nastia ${ }^{159}$, Nataliningsih ${ }^{160}$, Ni Wayan Nursini ${ }^{161}$, Nian Afrian Nuari $^{162}$, Nisaul Barokati Seliro Wangi ${ }^{163}$, Nita Yessirita ${ }^{164}$, Nopriadi ${ }^{165}$, Nova Christian Mamuaya ${ }^{126}$, Nova Susanti ${ }^{129}$, Nugrahini Kusumawati ${ }^{18}$, Nur Fauziah Siregar $^{166}$, Nurdiana Siregar ${ }^{167}$, Nurhidayah ${ }^{51}$, Nurmawati ${ }^{45}$, Nurussama ${ }^{168}$, Okma Yendri ${ }^{169}$, Okti Purwaningsih ${ }^{170}$, Patmawati ${ }^{51}$, Prehatin Trirahayu Ningrum $^{58}$, Pudentiana Rr R.E ${ }^{171}$, Purwo Subekti ${ }^{172}$, Putu Sukma Kurniawan ${ }^{173}$, Qashlim $^{51}$, R. Oktaviance S. ${ }^{174}$, Rahmad Hidayat ${ }^{175}$, Rahmat Hidayat ${ }^{176}$, Rahmi Fauzia $^{152}$, Rahmi Lubis ${ }^{177}$, Rama Kertamukti ${ }^{178}$, Rama Oktavian ${ }^{179}$, Ratna Dyah Suryaratri $^{107}$, Ratna Farwati ${ }^{180}$, Ratna Said ${ }^{159}$, Ratna Wati Simbolon ${ }^{181}$, Reni Yunus ${ }^{182}$, Retno Sari Dewi ${ }^{183}$, Reza Rachmadtullah ${ }^{107}$, Rezania Agramanisti Azdy $^{86}$, Rhini Fatmasari ${ }^{184}$, Ria Marginingsih ${ }^{185}$, Ricardo Freedom Nanuru ${ }^{186}$, Rina Novia Yanti ${ }^{21}$, Rina Septiani ${ }^{187}$, Rinandita Wikansari ${ }^{188}$, Ririen Wardiani ${ }^{189}$, Rita Sari ${ }^{190}$, Riyadh Arridha ${ }^{191}$, Rizki Priya Pratama ${ }^{192}$, Robbi Rahim ${ }^{156}$, Rochmady $^{193}$, Rosanita Tritias Utami ${ }^{35}$, Rosida Tiurma Manurung ${ }^{32}$, Ruki Ambar Arum ${ }^{194}$, Rustam ${ }^{195}$, Saiful Bahri ${ }^{196}$, Salniwati ${ }^{6}$, Santirianingrum Soebandhi $^{197}$, Sarono Widodo ${ }^{198}$, Sayyida ${ }^{199}$, Selpida Handayani ${ }^{40}$, Sitaresmi Wahyu Handani $^{77}$, Siti Juariah ${ }^{200}$, Siti Nurina Hakim ${ }^{154}$, Sitti Fithriani Saleh ${ }^{201}$, Sri Wahyuni ${ }^{21}$, Sri Winarni ${ }^{129}$, St Handana Utari ${ }^{202}$, Suhono ${ }^{203}$, Sukardin ${ }^{204}$, Sulfikar Sallu $^{195}$, Suliawati ${ }^{43}$, Sumitro ${ }^{205}$, Supriyadi ${ }^{10}$, Supriyanto ${ }^{206}$, Suriani ${ }^{207}$, Susiana Susiana' ${ }^{208}$, Suwarsih ${ }^{209}$, Syamsul Hidayat ${ }^{18}$, Syifa Saputra ${ }^{210}$, Tato Nuryanto $^{25}$, Taufiqurrahman ${ }^{30}$, Teguh Trianton ${ }^{211}$, Tien Zubaidah ${ }^{212}$, Titing Magfirah $^{191}$, Tonni Limbong ${ }^{213}$, Tri Listyorini ${ }^{116}$, Trio Pahlawan ${ }^{214}$, Tutut Suryaningsih $^{35}$, Upik Rahmi ${ }^{98}$, Uus Ahmad Husaeni ${ }^{215}$, Valentino Hary ${ }^{119}$, Veronika Nugraheni Sri Lestari ${ }^{83}$, Vieronica Varbi Sununianti ${ }^{180}$, Vivi Novalia Sitijak $^{146}$, Wanti Arumwanti ${ }^{216}$, Widodo ${ }^{217}$, Yance Sonatha ${ }^{33}$, Yansyah ${ }^{218}$, Yenni Kristin Panjaitan $^{219}$, Yetti ${ }^{21}$, Yohanes Dakhi ${ }^{20}$, Yudithia Dian Putra ${ }^{221}$, Yulia ${ }^{222}$, Yuliyanto Budi Setiawan ${ }^{60}$, Zainal Muktamar ${ }^{89}$, Zulfikar $^{223}$, A. Farida Arsal ${ }^{1}$, A. Irma Suryani Idris ${ }^{1}$, Abd. Muis ${ }^{1}$, Abdul Hadis ${ }^{1}$, Abdul Mun'im ${ }^{1}$, Abdurahman ${ }^{224}$, Achmad Kusairi Samlawi ${ }^{152}$, Ade Oktarino ${ }^{225}$, Adiatma ${ }^{1}$, Adnan ${ }^{1}$, Adrian Faridhi $^{21}$, Agung Purnomo ${ }^{226}$, Ahmad Bahtiar ${ }^{227}$, Ahmad Fauzul Hakim Hasibuann $^{228}$, Ahmad Fudhail Majid ${ }^{1}$, Ahmad Gunawan ${ }^{158}$, Ahmad Hasyim ${ }^{229}$, Ahmad Yani ${ }^{1}$, Ahmad Zaki ${ }^{1}$, Ainna Amalia $\mathbf{F N}^{230}$, Alfian Saleh ${ }^{21}$, Alimin ${ }^{1}$, Alimuddin $^{1}$, Amandus Jong Tallo ${ }^{231}$, Andi Akifah ${ }^{232}$, Andi Aprasing ${ }^{233}$, Andi Asmawati Azis ${ }^{1}$, Andi Dian Angriani ${ }^{234}$, Andi Nurani Mangkawani Arifin ${ }^{235}$, 
Andi Reni ${ }^{236}$, Andista Candra Yusro ${ }^{66}$, Andre Paulus Saleky ${ }^{12}$, Andri Nugraha ${ }^{237}$, Aneu Yulianeu ${ }^{238}$, Anik Vega Vitianingsih ${ }^{239}$, Anna Riana Suryanti Tambunan ${ }^{8}$, Ankardiansyah Pandu Pradana ${ }^{240}$, Ari Riswanto ${ }^{241}$, Arif Rahman Putra ${ }^{80}$, Arifah Novia Arifin $^{1}$, Arifin Ahmad ${ }^{242}$, Army Auliah ${ }^{1}$, Aryo Michael ${ }^{243}$, Asdar Ahmad ${ }^{1}$, Aswi $^{1}$, Aurellia Tatipata $^{82}$, Awi ${ }^{1}$, Ayub Wijayati Sapta Pradana ${ }^{244}$, Bambang Parmadi $^{89}$, Bayu Prabowo Sutjiatmo ${ }^{188}$, Bernard ${ }^{1}$, Bunga Dara Amin ${ }^{1}$, Busro ${ }^{245}$, Dahlan Abdullah $^{311}$, Daniel Silli Bataona ${ }^{106}$, Dedi Muhtadi ${ }^{246}$, Dedy Juliandri Panjaitan $^{247}$, Desi Ulpa Anggraini ${ }^{248}$, Dessy Agustina Sari ${ }^{42}$, Dewi Satria Ahmar $^{235,271}$, Diana Zuhroh ${ }^{249}$, Dicky Nofriansyah ${ }^{250}$, Dina Chamidah ${ }^{59}$, Djadir ${ }^{1}$, Dudung Ma'ruf Nuris ${ }^{56}$, Dwi Ely Kurniawan ${ }^{251}$, Dwi Nur Rachmah ${ }^{152}$, Ebin Eyzer Danius $^{252}$, Edi Fitriana Afriza ${ }^{246}$, Eka Fitriyana Hamsyah ${ }^{229}$, Eka Selvi Handayani $^{253}$, Eka Zuliana ${ }^{116}$, Eko Susanto ${ }^{254}$, Eli Jamilah Mihardja ${ }^{255}$, Ella Anastasya Sinambela ${ }^{80}$, Elsa Rosyidah ${ }^{256}$, Esther Kembauw ${ }^{257}$, Eva Desembrianita $^{258}$, Eva Nur Rachmah ${ }^{45}$, Evi Rinata ${ }^{259}$, Evy Nurvitasari ${ }^{260}$, Fajar Arwadi $^{1}$, Fajar Kusnadi Kusumah Putra ${ }^{216}$, Fajria Fatmasari ${ }^{188}$, Fandi Ahmad ${ }^{229}$, Fathimah Az-zahra ${ }^{261}$, Fika Megawati ${ }^{259}$, Fitriana Destiawati ${ }^{114}$, Fransiska Natalia Ralahallo ${ }^{82}$, Frijona F. Lokollo ${ }^{262}$, Gloria Christiana Manulangga ${ }^{106}$, Halimah Husain ${ }^{1}$, Halimatus Sakdiah ${ }^{263}$, Hambali Thalin ${ }^{40}$, Hamda ${ }^{1}$, Hani Sirine $^{53}$, Hardin ${ }^{1}$, Haris Munandar ${ }^{229}$, Harisa Mardiana ${ }^{264}$, Hary Hermawan ${ }^{265}$, Hasina Fajrin $\mathbf{R}^{266}$, Hasri ${ }^{1}$, Haviluddin ${ }^{292}$, Heri Nurdiyanto ${ }^{313}$, Hellna Tehubijuluw $^{82}$, Hendrati Dwi Mulyaningsih ${ }^{267}$, Hendri Dony Hahury ${ }^{82}$, Hengki Mangiring Parulian Simarmata ${ }^{268}$, Herfa Maulina Dewi Soewardini ${ }^{59}$, Heri Dwi Putranto $^{89}$, Herman ${ }^{1}$, Hifdhotul Munawaroh ${ }^{30}$, Hilda Karim ${ }^{1}$, I Nyoman Sudiana $^{6}$, Hisyam Ihsan ${ }^{1}$, Ibrahim ${ }^{1}$, Ilham Minggi ${ }^{1}$, Imas Srinana Wardani ${ }^{269}$, Inderawati $^{6}$, Irma Suriani Idris ${ }^{1}$, Irmawanty ${ }^{270}$, Irwan ${ }^{1}$, Irwana R. Badji ${ }^{271}$, Ismail $^{1}$, Iwan Dini ${ }^{1}$, Jacobus Cliff Diky Rijoly ${ }^{82}$, Jajang Burhanudin ${ }^{272}$, Jayanti Putri Purwaningrum ${ }^{116}$, Jehan Safitri ${ }^{152}$, Jogeneis Patty ${ }^{82}$, Johanna Rimbing ${ }^{126}$, Kaharuddin Arafah $^{1}$, Kamri Ahmad ${ }^{40}$, Khadijah ${ }^{229}$, Khoirul Ngibad ${ }^{273}$, Kristiana Sri Utami ${ }^{274}$, Kurniawan Harikesuma Ahmar ${ }^{235}$, Kustanto ${ }^{93}$, Laily Nurlina ${ }^{211}$, Leon Andretti Abdillah ${ }^{312}$, Lilik Istiqomah ${ }^{275}$, Liliza Agustin ${ }^{276}$, Lucky Nugroho $^{277}$, Lusy Tunik Muharlisiani ${ }^{59}$, M. Agus Martawijaya ${ }^{1}$, M. Mirza Abdillah Pratama ${ }^{56}$, M. Taufik Qurohman ${ }^{278}$, Maddatuang ${ }^{1}$, Maria Maghdalena Diana Widiastuti $^{24}$, Marissa Putriana ${ }^{95}$, Mas'ud Muhammadiyah ${ }^{261}$, Masyitah Noviyanti ${ }^{256}$, Maya Sari Wahyuni ${ }^{1}$, Melda Gienardy ${ }^{113}$, Memen Permata Azmi ${ }^{279}$, Meri Azmi $^{33}$, Mila Hariani ${ }^{80}$, Mirawati A. Tongko ${ }^{113}$, Moch. $\operatorname{Irfan}^{80}$, Mochammad Aldy Anwar ${ }^{256}$, Mochammad Noviadi Nugroho ${ }^{280}$, Mochammad Tanzil Multazam ${ }^{259}$, Moh. Yamin ${ }^{152}$, Mohammad Roesli ${ }^{281}$, Mohammad Wijaya M. ${ }^{1}$, Mugi Praseptiawan ${ }^{270}$, Muh Yunus ${ }^{229}$, Muh. Jaelani Al-Pansori ${ }^{147}$, Muhafidhah Novie $^{282}$, Muhammad Agus ${ }^{201}$, Muhammad Anwar ${ }^{1}$, Muhammad Aqil Rusli ${ }^{1}$, Muhammad Asfar ${ }^{236}$, Muhammad Danial', Muhammad Darwis ${ }^{1}$, Muhammad Jasri Djangi ${ }^{1}$, Muhammad Junda ${ }^{1}$, Muhammad Wiharto ${ }^{1}$, Muhammad Yahya Matdoan $^{82}$, Muhammad Yusuf ${ }^{283}$, Muhammad Yusuf ${ }^{284}$, Mujiarto ${ }^{314}$, Mukrimin $^{285}$, Mutahharah Hasyim ${ }^{1}$, Nalal Muna ${ }^{188}$, Nana Hendracipta ${ }^{157}$, Nani Kurnia $^{1}$, Nany Noor Kurniyati ${ }^{274}$, Natelda R. Timisela ${ }^{82}$, Neka Erlyani ${ }^{152}$, Netti Herawati $^{1}$, Nour Ardiansyah Hernadi ${ }^{286}$, Nur Indah Sari $^{229}$, Nuraini ${ }^{6}$, Nurhayati ${ }^{1}$, Nurhayati B. $^{1}$, Nurmawati ${ }^{45}$, Nurul Qamar ${ }^{40}$, Okki Trinanda ${ }^{224}$, Panji Kuncoro Hadi $^{66}$, Pariabti Palloan ${ }^{1}$, Parma Hadi Rantelinggi ${ }^{287}$, Pramita Laksitarahmi Isrianto $^{59}$, Prasetio Ariwibowo ${ }^{114}$, Purwati Zisca Diana ${ }^{288}$, Rahayu Mardikaningsih $^{80}$, Rahmadhani Fitri $^{289}$, Rainier Hendrik Sitaniapessy ${ }^{257}$, Rais Hidayat $^{290}$, Ramadona Simbolon ${ }^{43}$, Ramlawati ${ }^{1}$, Ramli Umar ${ }^{1}$, Ratnawaty Maming ${ }^{1}$, Restu Rahmawati ${ }^{105}$, Resy Nirawati ${ }^{22}$, Rika Vira Zwagery ${ }^{152}$, Rika 
Yuliana $^{291}$, Rini Apriyani ${ }^{292}$, Riski Muliyani ${ }^{22}$, Rizal Bakri ${ }^{293}$, Rizka Safriyani ${ }^{294}$, Rohana $^{1}$, Rosdiana Ngitung ${ }^{1}$, Rudi Abdullah ${ }^{159}$, Rudi Syahputra ${ }^{214}$, Rusli ${ }^{1}$, Safrizal $^{140}$, Sahlan Sidjara ${ }^{1}$, Riny Jefri ${ }^{1}$, Said Fachry Assagaf ${ }^{1}$, Samsul Arifin ${ }^{80}$, Setiabudhi $^{45}$, Sherlock Halmes Lekipiouw ${ }^{257}$, Sitti Hutari Mulyani ${ }^{111}$, Sitti Saenab $^{1}$, Sonny Kristianto ${ }^{59}$, Sowanto ${ }^{295}$, Sri Elviani $^{43}$, Sri Maryanti ${ }^{21}$, Sri Mukminati Nur ${ }^{229}$, Sri Puspa Dewi ${ }^{296}$, Sri Susilawati ${ }^{113}$, Sri Wiwoho Mudjanarko $^{7}$, St. Humaerah Syarif ${ }^{229}$, Stevanus Johan Gomies ${ }^{4}$, Sudarmin ${ }^{1}$, Sudding $^{1}$, Sugianto ${ }^{297}$, Sugiarti ${ }^{1}$, Suharto ${ }^{298}$, Sukarna ${ }^{1}$, Sulaiman Zhiddiq ${ }^{1}$, Suman Sangadji ${ }^{299}$, Suprapta ${ }^{1}$, Surahman Nur ${ }^{229}$, Susilo ${ }^{300}$, Sutamrin', Syamsiah $^{1}$, Syamsurijal Basri ${ }^{1}$, Taty Sulastry ${ }^{1}$, Taufik Bidullah ${ }^{113}$, Trian Pamungkas Alamsyah ${ }^{157}$, Tristan Rokhmawan ${ }^{301}$, Tuti Agustin ${ }^{48}$, Ulinnuha Madyananda ${ }^{48}$, Usmaedi ${ }^{270}$, Usman ${ }^{302}$, Uwes Fatoni $^{245}$, Vebtasvili ${ }^{222}$, Vera Theresia Caroline Siahaya ${ }^{4}$, Victor R. Pattipeilohy ${ }^{4}$, Widhy Wahyani ${ }^{303}$, Wahyudin Albra $^{311}$, Wiwiek Rindayati ${ }^{304}$, Wiwik Handayani ${ }^{305}$, Wiyanto ${ }^{306}$, Yeni Ika Pratiwi ${ }^{307}$, Yossie Yumiati ${ }^{308}$, Yudi juniardi ${ }^{157}$, Yuniningsih ${ }^{305}$, Yuska Noviyanty $^{309}$, Yusuf Rahman Al Hakim ${ }^{80}$, Yuuun Elizabeth Patras ${ }^{290}$, Zakaria Husein Abdurrahman ${ }^{310}$, Zulharbi Amatahir ${ }^{113}$, Zulkifli Rais ${ }^{229}$, Rahmat Hidayat $^{33}$, Juneman Abraham ${ }^{315}$

${ }^{1}$ Universitas Negeri Makassar, ${ }^{2}$ Universitas Padjadjaran, ${ }^{3}$ Institut Teknologi Bandung, ${ }^{4}$ Politeknik Negeri Ambon, ${ }^{5}$ Lembaga Ilmu Pengetahuan Indonesia, ${ }^{6}$ Universitas Halu Oleo, ${ }^{7}$ Narotama University, ${ }^{8}$ Universitas Negeri Medan, ${ }^{9}$ STMIK Nusa Mandiri Sukabumi, ${ }^{10}$ Universitas Serang Raya, ${ }^{11}$ STMIK AKBA Makassar, ${ }^{12}$ Sekolah Tinggi Keguruan dan Ilmu Pendidikan Biak, ${ }^{13}$ Sekolah Tinggi Teknik Malang, ${ }^{14}$ Universitas Prof. Dr. Hazairin SH, ${ }^{15}$ STIE Insan Pembangunan, ${ }^{16}$ STKIP PGRI Bangkalan, ${ }^{17}$ Institut Agama Islam Negeri Zawiyah Cotkala Langsa, ${ }^{18}$ Universitas Bina Bangsa,

${ }^{19}$ Politeknik Perikanan Negeri Tual, ${ }^{20}$ Institut Teknologi Adhi Tama Surabaya,

${ }^{21}$ Universitas Lancang Kuning, ${ }^{22}$ STKIP Singkawang, ${ }^{23}$ Universitas Nurul Jadid,

${ }^{24}$ Universitas Musamus Merauke, ${ }^{25}$ IAIN Syekh Nurjati Cirebon, ${ }^{26}$ Tanjungpura University, ${ }^{27}$ Sekolah Tinggi Hukum Bandung, ${ }^{28}$ STAI Miftahul Ula Nganjuk,

${ }^{29}$ Universitas Muhammadiyah Sorong, ${ }^{30}$ Universitas Darussalam Gontor, ${ }^{31}$ STMIK Bina Sarana Global, ${ }^{32}$ Universitas Kristen Maranatha, ${ }^{33}$ Politeknik Negeri Padang, ${ }^{34}$ STMIK Nusa Mandiri Jakarta, ${ }^{35}$ STKIP PGRI Tulungagung, ${ }^{36}$ STKIP PGRI Banjarmasin, ${ }^{37}$ Poltekkes Kemenkes Yogyakarta, ${ }^{38}$ STIKES Tengku Maharatu Pekanbaru, ${ }^{39}$ Universitas Airlangga, ${ }^{40}$ Universitas Muslim Indonesia, ${ }^{41}$ STKIP PGRI Lamongan, ${ }^{42}$ Universitas Singaperbangsa Karawang, ${ }^{43}$ Universitas Islam Sumatera Utara, ${ }^{44}$ Universitas Graha Nusantara, ${ }^{45}$ Universitas 45 Surabaya, ${ }^{46}$ Universitas Yudharta Pasuruan, ${ }^{47}$ Universitas Muhammadiyah Ponorogo, ${ }^{48}$ Universitas Sebelas Maret, ${ }^{49}$ IKIP PGRI Bojonegoro, ${ }^{50}$ Universitas Widya Dharma, ${ }^{51}$ Universitas Al Asyariah Mandar, ${ }^{52}$ Universitas Muhammadiyah Tangerang, ${ }^{53}$ Universitas Kristen Satya Wacana Salatiga, ${ }^{54}$ Universitas Indo Global Mandiri, ${ }^{55}$ AMIK BSI Sukabumi, ${ }^{56}$ Universitas Negeri Malang, ${ }^{57}$ Universitas Galuh, ${ }^{58}$ Universitas Jember, ${ }^{59}$ Universitas Wijaya Kusuma Surabaya, ${ }^{60}$ Universitas Semarang, ${ }^{61}$ STIKES Fort De Kock Bukittinggi, ${ }^{62}$ STIE Muhammadiyah Jakarta, ${ }^{63}$ Sekolah Tinggi Ilmu Ekonomi Gempol, ${ }^{64}$ Universitas Jenderal Achmad Yani, ${ }^{65}$ Universitas Muhammadiyah Luwuk, ${ }^{66}$ Universitas PGRI Madiun, ${ }^{67}$ Universitas Ibn Khaldun Bogor, ${ }^{68}$ Universitas Kristen Satya Wacana, ${ }^{69}$ Akademi Pelayaran Niaga Indonesia, ${ }^{70}$ Politeknik TEDC Bandung, ${ }^{71}$ Poltekkes Aceh, ${ }^{72}$ Politeknik LP3I Jakarta, ${ }^{73}$ Universitas Nahdlatul Wathan Mataram, ${ }^{74}$ Universitas Dr Soetomo, ${ }^{75}$ Universitas Budi Luhur, ${ }^{76}$ STIE Rahmaniya Sekayu, ${ }^{77}$ STMIK AMIKom Purwokerto, ${ }^{78}$ STIKES Mercubaktijaya Padang, ${ }^{79}$ Universitas Islam Kalimantan MAB Banjarmasin, ${ }^{80}$ Universitas Mayjen Sungkono,

${ }^{81}$ UIN Raden Fatah, ${ }^{82}$ Universitas Pattimura, ${ }^{83}$ Universitas Dr. Soetomo, ${ }^{84}$ STIE PGRI 
Dewantara Jombang, ${ }^{85}$ Politeknik PIKSI Ganesha, ${ }^{86}$ STMIK Palcomtech, ${ }^{87}$ Universitas Pamulang, ${ }^{88}$ STKIP PGRI Blitar, ${ }^{89}$ Universitas Bengkulu, ${ }^{90}$ Universitas Trisakti, ${ }^{91}$ Sekolah Tinggi Ilmu Ekonomi Riau, ${ }^{92}$ STKIP Persada Khatulistiwa Sintang, ${ }^{93}$ Universitas Islam Balitar, ${ }^{94}$ Universitas Yarsi, ${ }^{95}$ Universitas Batanghari Jambi, ${ }^{96}$ University of Jember, ${ }^{97}$ Universitas Muhammadiyah Sumbar, ${ }^{98}$ Universitas Pendidikan Indonesia, ${ }^{99}$ Sekolah Tinggi Ilmu Administrasi Mataram, ${ }^{100}$ AMIK Stiekom Sumatera Utara, ${ }^{101}$ STMIK Bina Patria, ${ }^{102}$ Universitas Wiralodra, ${ }^{103}$ Politeknik Palcomtech Palembang, ${ }^{104}$ UIN Jakarta, ${ }^{105}$ Universitas 17 Agustus 1945 Jakarta, ${ }^{106}$ Politeknik Negeri Kupang, ${ }^{107}$ Universitas Negeri Jakarta, ${ }^{108}$ Universitas Dharmas Indonesia, ${ }^{109}$ Pusdiklat Kementerian Agraria dan Tata Ruang/Badan Pertanahan Nasional, ${ }^{110}$ Sekolah Tinggi Teknik Harapan, ${ }^{111}$ Universitas Putra Indonesia YPTK Padang, ${ }^{112}$ Akademi Keperawatan Rumkit Tk. III Dr.J.A.Latumeten Ambon, ${ }^{113}$ Universitas Tompotika Luwuk, ${ }^{114}$ Universitas Indraprasta PGRI, ${ }^{115}$ Balai Penelitian Tanaman Pemanis dan Serat Malang, ${ }^{116}$ Universitas Muria Kudus, ${ }^{117}$ Universitas Kanjuruhan Malang, ${ }^{118}$ Universitas Muhammadiyah Sumatera Utara, ${ }^{119}$ Universitas Nahdlatul Ulama Blitar, ${ }^{120}$ Universitas Sany Bumi Ruwa Jurai, ${ }^{121}$ STIKOM Tunas Bangsa, ${ }^{122}$ Universitas Bhayangkara Jakarta Raya, ${ }^{123}$ Universitas Negeri Gorontalo, ${ }^{124}$ Universitas Nusantara Pgri Kediri, ${ }^{125}$ Universitas Simalungun, ${ }^{126}$ Universitas Negeri Manado, ${ }^{127}$ Universitas HKBP Nommensen Medan, ${ }^{128}$ STAKPN Ambon, ${ }^{129}$ Universitas Jambi, ${ }^{130}$ STMIK Lombok, ${ }^{131}$ Sekolah Tinggi Ilmu Pertanian Rejang Lebong, ${ }^{132}$ Institut Agama Islam Negeri Kendari, ${ }^{133}$ STIKES Bina Generasi Polewali Mandar, ${ }^{134}$ STAI Pelita Bangsa, ${ }^{135}$ Politeknik Negeri Madiun, ${ }^{136}$ Universitas Iqra Buru, ${ }^{137}$ Universitas Flores, ${ }^{138}$ Politeknik Medica Farma Husada Mataram, ${ }^{139}$ STAI Auliya Urasyiddin Tembilahan, ${ }^{140}$ Universitas Samudra, ${ }^{141}$ Politeknik ATI Makassar, ${ }^{142}$ Universitas Islam Indonesia, ${ }^{143}$ Universitas Riau, ${ }^{144}$ Universitas Muhammadiyah Palangkaraya, ${ }^{145}$ Universitas Harapan Medan, ${ }^{146}$ Universitas Methodist Indonesia, ${ }^{147}$ Universitas Hamzanwadi, ${ }^{148}$ Institut Ilmu Kesehatan Bhakti Wiyata Kediri, ${ }^{149}$ Universitas Islam Negeri Sunan Ampel, ${ }^{150}$ Universitas Yapis Papua, ${ }^{151}$ Universitas Cokroaminoto Palopo, ${ }^{152}$ Universitas Lambung Mangkurat, ${ }^{153}$ Politeknik Ganesha Medan, ${ }^{154}$ Universitas Muhammadiyah Surakarta, ${ }^{155}$ Universitas PGRI Palembang, ${ }^{156}$ Institut Teknologi Medan, ${ }^{157}$ Universitas Sultan Ageng Tirtayasa, ${ }^{158}$ STIE Pelita Bangsa, ${ }^{159}$ Universitas Muhammadiyah Buton, ${ }^{160}$ Universitas Winaya Mukti, ${ }^{161}$ Universitas Dhyana Pura, ${ }^{162}$ STIKES Karya Husada Kediri, ${ }^{163}$ Universitas Islam Darul Ulum Lamongan, ${ }^{164}$ Universitas Ekasakti, ${ }^{165}$ Universitas Putera Batam, ${ }^{166}$ Institut Agama Islam Negeri Padangsidimpuan, ${ }^{167}$ Universitas Nahdlatul Ulama Sumatera Utara, ${ }^{168}$ Politeknik Palcomtech, ${ }^{169}$ Universitas Musi Rawas, ${ }^{170}$ Universitas PGRI Yogyakarta, ${ }^{171}$ Politeknik Kesehatan Kemenkes Jakarta I, ${ }^{172}$ Universitas Pasir Pengaraian, ${ }^{173}$ Universitas Pendidikan Ganesha, ${ }^{174}$ STIKES Santa Elisabeth Medan, ${ }^{175}$ Sekolah Tinggi Teknologi Mandala, ${ }^{176}$ Sekolah Tinggi Ilmu Manajemen Sukma Medan, ${ }^{177}$ Universitas Medan Area, ${ }^{178}$ UIN Sunan Kalijaga, ${ }^{179}$ Universitas Brawijaya, ${ }^{180}$ Universitas Sriwijaya, ${ }^{181}$ AMIK Medan Business Polytechnic, ${ }^{182}$ Poltekkes Kemenkes Kendari, ${ }^{183}$ Universitas Tulungagung, ${ }^{184}$ Universitas Terbuka Jakarta, ${ }^{185}$ Universitas Islam 45 Bekasi, ${ }^{186}$ Universitas Halmahera, ${ }^{187}$ Universitas Tama Jagakarsa, ${ }^{188}$ Politeknik APP Jakarta, ${ }^{189}$ STKIP PGRI Ponorogo, ${ }^{190}$ IAIN Langsa, ${ }^{191}$ Politeknik Negeri Fakfak, ${ }^{192}$ Politeknik Kota Malang, ${ }^{193}$ Sekolah Tinggi Ilmu Pertanian Wuna Raha, ${ }^{194}$ Politeknik Informatika Nasional, ${ }^{195}$ Universitas Sembilanbelas November Kolaka, ${ }^{196}$ IKIP PGRI Pontianak, ${ }^{197}$ Universitas Narotama, ${ }^{198}$ Politeknik Negeri Semarang, ${ }^{199}$ Universitas Wiraraja, ${ }^{200}$ Akademi Analis Kesehatan Pekanbaru, ${ }^{201}$ Universitas Muhammadiyah Makassar, ${ }^{202}$ Universitas Madako, ${ }^{203}$ Universitas Gadjah Mada, ${ }^{204}$ Sekolah Tinggi Ilmu Kesehatan Mataram, ${ }^{205}$ AMIK Labuhan Batu, ${ }^{206}$ Bogor Agricultural University, ${ }^{207}$ STIE Tri Dharma Nusantara 
Makassar, ${ }^{208}$ Universitas Maritim Raja Ali Haji, ${ }^{209}$ Universitas PGRI Ronggolawe Tuban, ${ }^{210}$ Universitas Al Muslim, ${ }^{211}$ Universitas Muhammadiyah Purwokerto, ${ }^{212}$ Poltekes Kemenkes Banjarmasin, ${ }^{213}$ Universitas Katolik Santo Thomas Medan, ${ }^{214}$ Politeknik Negeri Lhokseumawe, ${ }^{215}$ Universitas Suryakancana, ${ }^{216}$ Sekolah Tinggi Pariwisata Bandung, ${ }^{217}$ Universitas Muhammadiyah Yogyakarta, ${ }^{218}$ Universitas Muhammadiyah Banjarmasin, ${ }^{219}$ Universitas Darma Agunga, ${ }^{220}$ STIE Nias Selatan, ${ }^{221}$ STIE IBMT Surabaya, ${ }^{222}$ Universitas Bangka Belitung, ${ }^{223}$ Universitas KH A Wahab Hasbullah, ${ }^{224}$ Universitas Negeri Padang, ${ }^{225}$ Universitas Adiwangsa Jambi, ${ }^{226}$ BINUS Institute of Creative Technology, ${ }^{227}$ UIN Syarif Hidayatullah, ${ }^{228}$ Universitas Pembangunan Panca Budi Medan, ${ }^{229}$ STKIP Pembangunan Indonesia Makassar, ${ }^{230}$ STAI Miftahul Ula Nglawak Kertosono, ${ }^{231}$ Universitas Agung Podomoro, ${ }^{232}$ Universitas Tadulako Palu, ${ }^{233}$ Universitas Sulawesi Barat, ${ }^{234}$ Universitas Islam Negeri Alauddin Makassar, ${ }^{235}$ AHMAR Institute, ${ }^{236}$ Universitas Hasanuddin, ${ }^{237}$ STIKES Karsa Husada Garut, ${ }^{238}$ STMIK DCI, ${ }^{239}$ Universitas Dr. Soetomo, ${ }^{240}$ Universitas Borneo Tarakan, ${ }^{241}$ STKIP PGRI Sukabumi, ${ }^{242}$ Universitas Pasundan, ${ }^{243}$ STMIK Kreatindo Manokwari, ${ }^{244}$ Universitas Islam Malang, ${ }^{245}$ UIN Sunan Gunung Djati Bandung, ${ }^{246}$ Universitas Siliwangi, ${ }^{247}$ Universitas Muslim Nusantara A1 Washliyah, ${ }^{248}$ STIE Rahmaniyah Sekayu, ${ }^{249}$ Universtas 45 Surabaya, ${ }^{250}$ STMIK Triguna Dharma, ${ }^{251}$ Politeknik Negeri Batam, ${ }^{252}$ Universitas Hein Namotemo, ${ }^{253}$ Universitas Widya Gama Mahakam Samarinda, ${ }^{254}$ Universitas Muhammadiyah Metro, ${ }^{255}$ Universitas Bakrie, ${ }^{256}$ Universitas Nahdlatul Ulama Sidoarjo, ${ }^{257}$ Universitas Pattimura Ambon, ${ }^{258}$ STIE Urip Sumoharjo Surabaya, ${ }^{259}$ Universitas Muhammadiyah Sidoarjo, ${ }^{260}$ Universitas Musamus, ${ }^{261}$ Universitas Bosowa Makassar, ${ }^{262}$ Univetsitas Pattimura, ${ }^{263}$ STKIP M Sungai Penuh, ${ }^{264}$ Universitas Buddhi Dharma, ${ }^{265}$ STP ARS Internasional Bandung, ${ }^{266}$ Balai Bahasa Sulawesi Selatan, ${ }^{267}$ Telkom University, ${ }^{268}$ Politeknik Bisnis Indonesia, ${ }^{269}$ Universitas PGRI Adi Buana Surabaya, ${ }^{270}$ STKIP Setiabudhi, ${ }^{271}$ STKIP YAPTI Jeneponto, ${ }^{272}$ Politeknik LP3I Bandung, ${ }^{273}$ Universitas Ma'arif Hasyim Latif Sidoarjo, ${ }^{274}$ Universitas Widya Mataram, ${ }^{275}$ IAIN Surakarta, ${ }^{276}$ UIN Sulthan Syarif Kasim Riau, ${ }^{277}$ Universitas Mercu Buana Jakarta, ${ }^{278}$ Politeknik Harapan Bersama, ${ }^{279}$ Universitas Islam Negeri Sultan Syarif Kasim Riau, ${ }^{280}$ UIN Syarif Hidayatullah Jakarta, ${ }^{281}$ Univeritas Merdeka Surabaya, ${ }^{282}$ Universitas NU Sidoarjo, ${ }^{283}$ Institut Sains \& Teknologi AKPRIND, ${ }^{284}$ Universitas Asahan, ${ }^{285}$ IAIN Sultan Amai, ${ }^{286}$ Sekolah Yinggi Pariwisata Ambarrukmo, ${ }^{287}$ Universitas Papua, ${ }^{288}$ Universitas Sarjanawiyata Tamansiswa, ${ }^{289}$ Universitas Pembangunan Panca Budi, ${ }^{290}$ Universitas Pakuan, ${ }^{291}$ UIN Ar-Raniry Banda Aceh, ${ }^{292}$ Universitas Mulawarman, ${ }^{293}$ STIEM Bongaya, ${ }^{294}$ UIN Sunan Ampel Surabaya, ${ }^{295}$ STKIP Bima, ${ }^{296}$ Universitas A1 Azhar Medan, ${ }^{297}$ Universitas Islam Negeri Sumatera Utara, ${ }^{298}$ Universitas Negeri Semarang, ${ }^{299}$ Universitas Darussalam Ambon, ${ }^{300}$ Universitas Muhammadiyah Prof.DR.Hamka, ${ }^{301}$ STKIP PGRI PASURUAN, ${ }^{302}$ Politeknik Bosowa, ${ }^{303}$ Sekolah Tinggi Teknologi POMOSDA Nganjuk, ${ }^{304}$ Institut Pertanian Bogor, ${ }^{305}$ Universitas Pembangunan Nasonal Veteran Jawa Timur, ${ }^{306}$ Sekolah Tinggi Teknologi Pelita Bangsa, ${ }^{307}$ Universitas Merdeka Surabaya, ${ }^{308}$ Universitas Dehasen Bengkulu, ${ }^{309}$ Akademi Farmasi Al-Fatah Bengkulu, ${ }^{310}$ Universitas Boyolali, ${ }^{311}$ Universitas Malikussaleh Aceh, ${ }^{312}$ Universitas Bina Darma, ${ }^{313}$ STMIK Dharma Wacana, ${ }^{314}$ Universitas Muhammadiyah Tasikmalaya, ${ }^{315}$ Bina Nusantara University.

ansarisaleh@unm.ac.id

Abstract. The Ministry of Research, Technology and Higher Education of Indonesia has introduced several national and international indexers of scientific works. This policy becomes a guideline for lecturers and researchers in choosing the reputable publications. This study aimed to describe the understanding level of Indonesian lecturers related to indexing databases, 
i.e. SINTA, DOAJ, Scopus, Web of Science, and Google Scholar. This research used descriptive design and survey method. The populations in this study were Indonesian lecturers and researchers. The primary data were obtained from a questionnaire filled by 316 lecturers and researchers from 33 Provinces in Indonesia recruited with convenience sampling technique on October-November 2017. The data analysis was performed using frequency distribution tables, cross tabulation and descriptive analysis. The results of this study showed that the understanding of Indonesian lecturers and researchers regarding publications in indexing databases SINTA, DOAJ, Scopus, Web of Science and Google Scholar is that, on average, $66,5 \%$ have known about SINTA, DOAJ, Scopus, Web of Science and Google Scholar. However, based on empirical frequency $76 \%$ of them have never published with journals or proceedings indexed in Scopus.

\section{Introduction}

The tight competition in the globalization era has penetrated to all aspects of life, including at the aspect of science and technology development. In accordance with Indonesian Law No. 12 of 2013 on Higher Education, lecturers have the duty and the responsibility to develop science and technology through scientific research and dissemination. The Indonesian Government through the Ministry of Research, Technology and Higher Education (Kemenristekdikti) encourages Indonesian academics to compete with academics of other countries, especially in the scope of ASEAN. There are currently 277.564 lecturers in Indonesia. The number of lecturers and researchers in Indonesia is far more than other countries in ASEAN such as Singapore. However, the number does not correspond with publication in scientific journal. For example, the number of publications of Indonesian lecturers and researchers indexed in Scopus and/or Web of Science is still below Malaysia.

The low of publications number in reputable journals or proceedings has raised some important policies for the scientific publications development of lecturers and researchers in Indonesia such as the advices for publishing in journal or reputable proceedings, national journals accreditation, the consideration of impacts of journals, attention to number of citations, and H-Index of authors. Publications in the digital age have the consequences on the impact of a publication through digital media, so the impact of an article is no longer only seen from the number of citations, but can also be seen from how much of a scientific work is clicked, shared, saved or downloaded, discussed, adapted and reviewed in an online forum [1]. Figure 1 shows the development of Scopus-indexed Indonesian publications from year to year.

One of the references of Kemenristekdikti in determining the reputation of a journal or proceedings is the national and international accreditation and indexing bodies. For example, journals indexed in Scopus or Web of Science are categorized as high reputable Journals, journals indexed in DOAJ are categorized as medium reputable journals and journals indexed solely in Google Scholar are categorized as low reputation journals. This policy summary can be seen at the Regulation of the Minister of Research, Technology and Higher Education (Permenristekdikti) No. 20 of 2017 and the Guideline of Credit Score Assessment (PAK) of Indonesian lecturers.

Based on Permenristekdikti No.20 of 2017, to obtain the professional lecture allowances and the professors honorary allowances, a lecturer who has certain academic position, e.g. Associate Professor and Professor, are required to publish with reputable international journals as part of their duties and responsibilities of scientists, in this case at least 1 article per year. Furthermore, the Regulation of the Minister of State Apparatus Empowerment and Bureaucratic Reform Number 17 of 2013 about the Lecturer's Functional Position and the Credit Score obliges lecturers with the position of Instructor and Assistant Professor to conduct scientific publications. Based on Forlap PDDIKTI data recap, academic year 2016/2017, the number of lecturers who have academic position of Associate Professor is 29.287, where Professor is 4.949, as shown in Figure 2. 


\section{Publications per Year on Scopus' and Google}

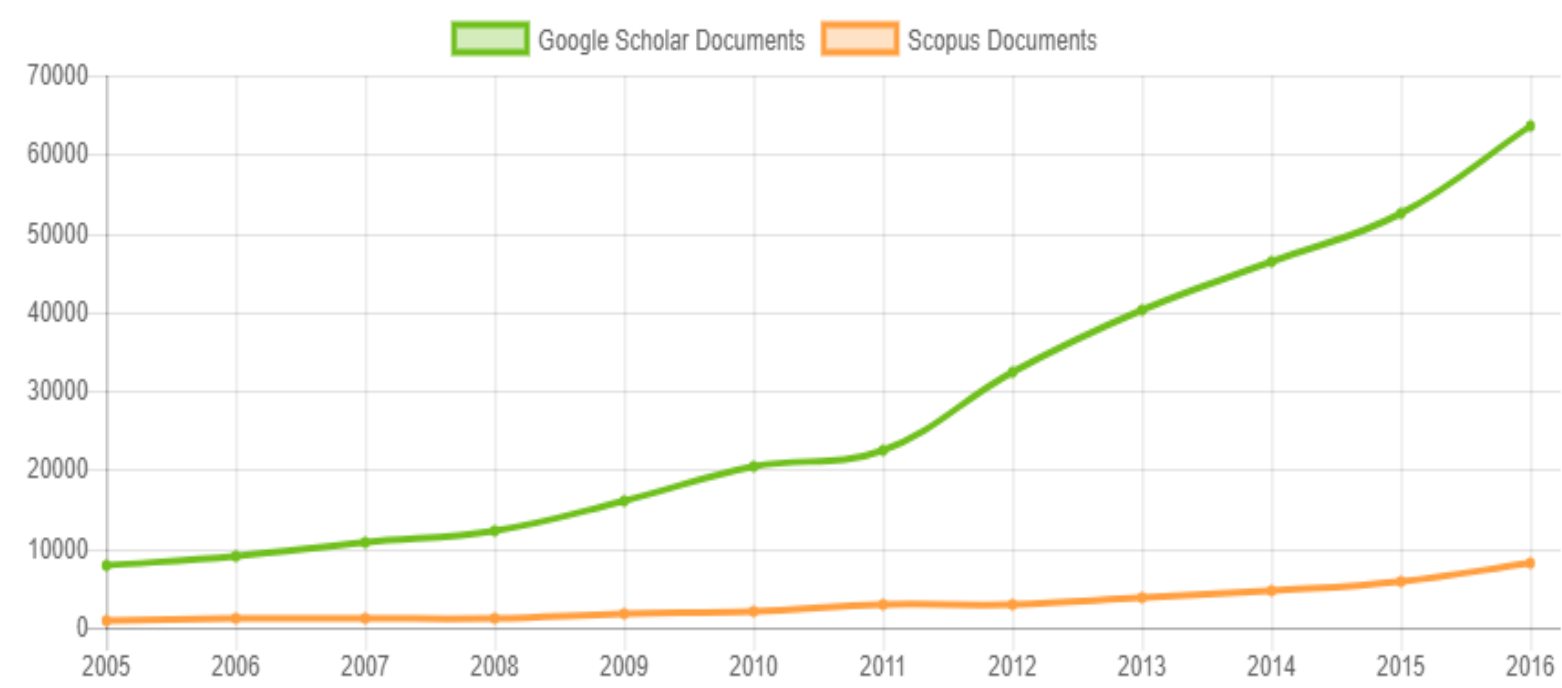

Figure 1. Indonesia-indexed publication Scopus and Google Scholar from 2005-2016

(Source: http://SINTA2.ristekdikti.go.id/)

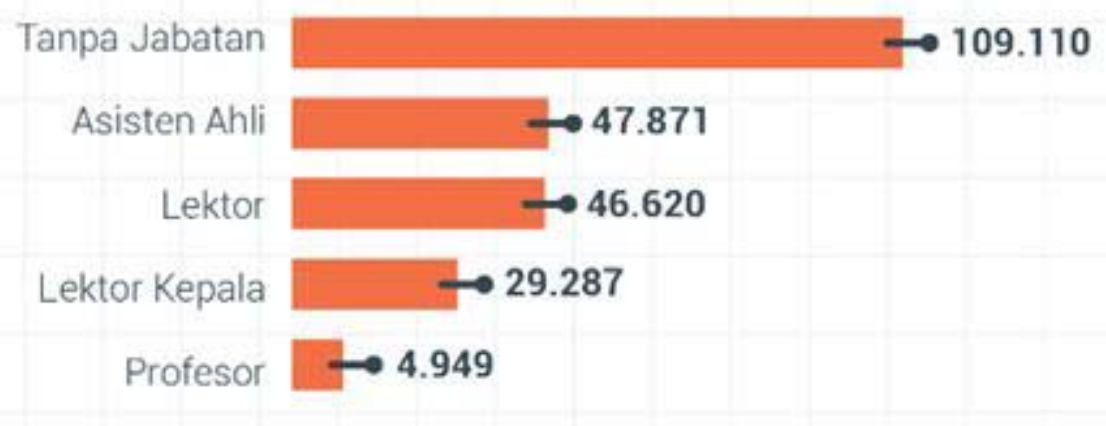

Figure 2. The distribution of lectures functional position

(Source: http://forlap.ristekdikti.go.id - Kemenristekdikti 2016/2017)

Notes: Tanpa Jabatan $=$ Tutor/Lecturer without a position; Asisten Ahli $=$ Lecturer $;$ Lektor $=$ Senior

Lecturer/Assistant Professor; Lektor Kepala= Associate Professor; Profesor $=$ Professor

The large numbers of lecturers who have position both the Associate Professor and Professor would be a great potential to increase the number of Indonesian publications at reputable international journals. Publication in international journals would be an achievement to increase the impact and lecturer's competitiveness in Indonesia. The capacity building and the lecturer competence need to be continuously encouraged. In addition, the journal publication is also a contribution of knowledge from a lecturer to be known by the public. Therefore, the results of research can be used in appropriate way in line with the original purpose of the research. By the existence of the publication bodies in Indonesia, inventions from abroad would be a complementary thing because the use of direct findings of Indonesian Scientists are so rich that could be found in the journals published in the country itself. 
Moreover, the development and competence of lecturers should continue to be encouraged and also full supported by the universities where the lecturers are serving.

Amidst the publication incentive situation, lecturers are challenged to think strategically in producing scientific papers in order to get career paths ranging from faculty to professors, and in assessing their selves compared with the criteria included in the policies developed by the Government in the scientific field. This present study aimed at investigating the level of lecturers' understanding in Indonesia about indexing databases, i.e. SINTA, DOAJ, Scopus, Web of Science and Google Scholar. Lecturers need to increase their literacy on the knowledge of various types of indexing databases of scientific works.

\section{Research Methods}

This research used survey research method. The population in this study is lecturers and researchers of Indonesia. Primary data were obtained from a questionnaire filled by 316 lecturers and researchers from 33 Provinces in Indonesia taken with convenience sampling technique during October until November 2017. Data analysis was performed using frequency distribution tables, cross tabulation and descriptive analysis.

\section{Result}

In this section will explained about the level of understanding of Indonesian lecturers related to the publications in indexed by SINTA, DOAJ, Scopus, Web of Science, and Google Scholar.

\subsection{Publication of Indonesian Lectures and Researchers}

The lack of lectures' understanding toward indexed journal is caused by several things, e.g. lecturers are not familiar with publication metrics. For example, not all lecturers have known the citation counting technology. The function of indexed journal is not socialized massively. Only a few of lecturers have participated in the training on indexed journals. There is also a biased paradigm that the publication is only for filing work requirements, to get academic credit point, to meet the obligations of Lecturer Performance Indicator. When one finds his/her point "sufficient" in terms of ongoing credit point saving, the desire to continue the contribution of their publication to the globe is decreasing; local journal is then enough for them. This "comfort" feeling is what makes many lecturers lag in searching for the information and shocked by the development of indexed journals. It is not only about the lecturers' ability to understand and to follow the journal guideline but also the deficient writing culture. This is further exacerbated by the minimal research support facilities and low research funding at some of the new born universities. All of those factors influence make the research output is not of the best so that researchers are not confident to enter the article on indexed journals.

A good understanding of published and indexed journal publications will spark the lectures spirit to conduct the quality research and to improve publishing capabilities. Table 1 presents data on the publication experience of lecturer in a scientific journal. It shows that the experience of journal publication can quantitatively be said good although the quality of the papers could still be questioned and requires more examination. Almost all Indonesian lecturers surveyed in this research have published a scientific work in a scientific journal indicating that Indonesian lecturers know about scientific writing techniques the publication technique.

The interesting points from the data in Table 1 are that 4,23\% of Tutor and 1,11\% of Assistant Professor have never published their scientific work in a journal. Meanwhile, research activity is one of the elements assessed by the credit score assessors team in determining a functional position of Indonesian lecturers. This is still possible because the assessment is measuring not only publication in the journal but also in the form of books, monographs, journals, proceedings of seminars or conferences, scientific works saved in libraries, book translation or editing, and intellectual property rights. However, the credit point for the conference proceedings is generally lower than the publication in the journal. As many as $10 \%$ of Tutors have never published a scientific paper in a journal. It may be a natural thing because they are usually a new lecturer. 
Table 1. Publication Experience in Journal

\begin{tabular}{ccc}
\hline \multirow{2}{*}{ Functional Position } & \multicolumn{2}{c}{ Ever published in a journal } \\
& No $(\%)$ & Yes $(\%)$ \\
\hline Tutor & 10,00 & 90,00 \\
Lecturer & 4,23 & 95,77 \\
Assistant Professor & 1,11 & 98,89 \\
Associate Professor & 0,00 & 100,00 \\
Professor & 0,00 & 100,00 \\
\hline
\end{tabular}

\subsection{Knowledge of Indonesian Lectures and Researchers on Indexing Databases}

3.2.1. SINTA. Science and Technology Index (SINTA) is a portal that serves to measure the performance of science and technology development in Indonesia. Indicators assessed are the results of research that has been done by researchers, lecturers, and institutions. The advantages of SINTA compared to other indexing portals that is can automatically indexing the work that has been indexed in Google Scholar and Scopus. The Minister of Research, Technology and Higher Education, Mohamad Nasir said the portal was created because the both number of students and lecturers has not been comparable yet with the number of publications produced so effecting Indonesian researchers less well known by the global community.

Up to November 6, 2017, only 5.153 lecturers have registered and verified in SINTA (http://SINTA2.ristekdikti.go.id/). Some lecturers who have not registered with SINTA because they still did not get socialization yet about SINTA and some others still think that SINTA is only a product that is still in experimental stage and may change again both in terms of rules and systems at the future. Some other lecturers also consider SINTA not having their own original data and only depending on data held by Google Scholar and Scopus. Somehow, it makes the most of Indonesian lecturers did not know about another indexing database like DOAJ (see below). This also raises one big question that is how the fate of SINTA if then there are problems "arise" from Google Scholar and Scopus itself. If it is not anticipated, this will be a big problem, so the government needs to think about having their own database center. However, the government's effort to record the publication of lecturers in Indonesia through SINTA should be appreciated.

Through SINTA, lecturers can easily view the contribution of universities and research institutions as well as the lecturer's personal contribution toward indexed documents by Scopus and Google Scholar, as shown in Figure 3. Figure 3 shows that Institut Teknologi Bandung (ITB) is an educational institution that contributes most Scopus-indexed documents registered in the SINTA portal, while Institut Pertanian Bogor (IPB) is the largest educational institution that contributes most documents to Google Scholar registered in the SINTA portal. Figure 3 also shows the contribution of The Indonesian Institute of Sciences (LIPI) is ranked at $8^{\text {th }}$ in the contribution of Scopus indexed documents and $7^{\text {th }}$ position for the contribution of Google Scholar indexed documents.

Ranking process of colleges and authors in the SINTA could spur authors for publishing intensively on reputable journals and increasing the number of citation as well as achieving SINTA score of colleges and themselves. The knowledge of Indonesian lecturers and researchers on SINTA can be seen in Table 2. Table 2 shows that most lecturers with various levels of functional positions have known about SINTA (the new indexer launched by Kemenristekdikti) indicating that the socialization about SINTA is successful. One of the success factors of socialization is the existence of link between ownership accounts in SINTA with the lecturer existence as a researcher. The registration in the SINTA has raised. However, it is viewed by some lecturers only as an obligation. 

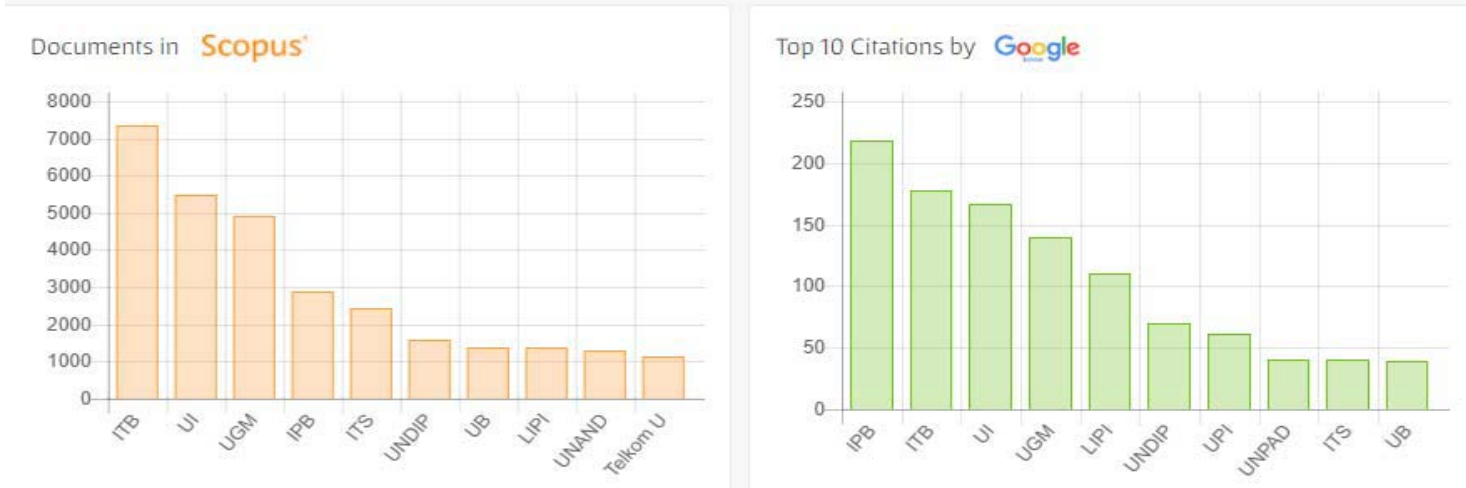

Figure 3. The Contribution of Universities and Research Institutions in Indonesia to Scopus and Google Scholar Indexed Documents (Source: http://SINTA2.ristekdikti.go.id/)

Table 2. Knowledge on SINTA

\begin{tabular}{ccc}
\hline \multirow{2}{*}{ Functional Position } & \multicolumn{2}{c}{ Knowledge on SINTA } \\
& No $(\%)$ & Yes $(\%)$ \\
\hline Tutor & 10,00 & 90,00 \\
Lecturer & 12,68 & 87,32 \\
Assistant Professor & 11,11 & 88,89 \\
Associate Professor & 3,33 & 96,67 \\
Professor & 0,00 & 100,00 \\
\hline
\end{tabular}

3.2.2. DOAJ. DOAJ (Directory of Open Access Journal) is a community-curated online directory that indexes and provides access to high quality, open access, peer-reviewed journals. DOAJ is independent. All funding is via donations, 50\% of which comes from sponsors and 50\% from members and publisher members. All DOAJ services are free of charge including being indexed in DOAJ. All data is freely available. DOAJ is launched in 2013 at Lund University, Sweden. At the time of launch there were about 300 journals open access that joined in it. Over time, the open access journals joined DOAJ range from 9.000 journals covering all areas of technology, science, medicine and social science studies. In order for a journal to be indexed in DOAJ then the main requirement is that the journal must be Open Access. Open Access is a condition where the journal can be read and accessed by everyone without any cost [2][3]. DOAJ measures the accessibility of a journal without a quality ranking system. However, DOAJ also provides a standard of DOAJ Seal to demonstrate the best practice of an Open Access (OA) journal where in Indonesia only 1 journal obtains DOAJ Seals similar to those occurring in the country Brazil.

Figure 4 shows the number of OA journals indexed by DOAJ from different countries (Top 50). It can be seen from the graphic that the countries order based on the number of journals indexed DOAJ (Top 5) are Brazil, United Kingdom, United States, Egypt, and Indonesia [4]. Table 3 shows that lecturers' knowledge on DOAJ is less when compared to other indexers. 


\section{OA journals (top 50 countries)}

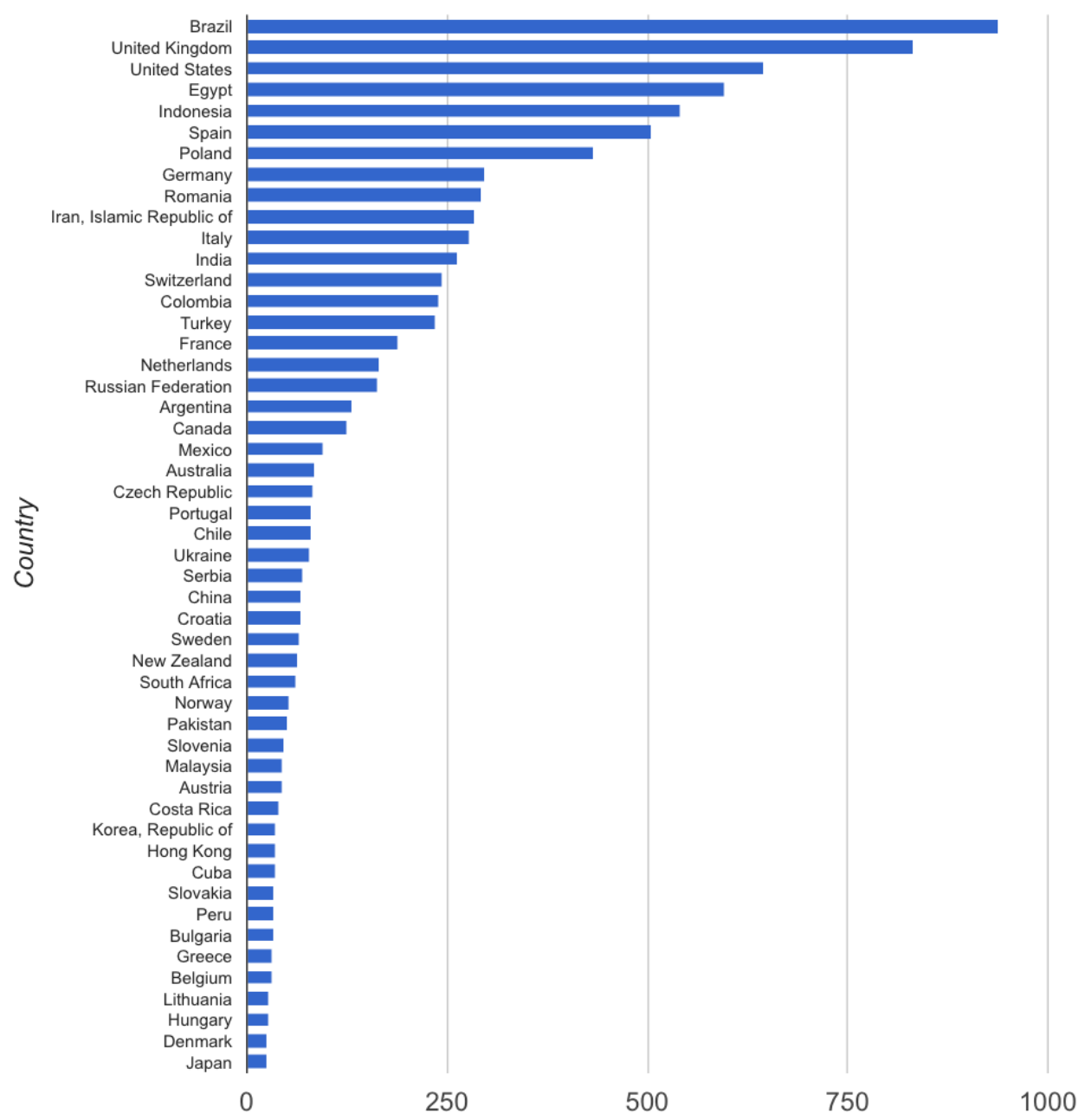

Figure 4 Number of Journals Indexed in DOAJ

Table 3. Knowledge on DOAJ

\begin{tabular}{ccc}
\hline \multirow{2}{*}{ Functional Position } & \multicolumn{2}{c}{ Knowledge on DOAJ } \\
& No $(\%)$ & Yes $(\%)$ \\
\hline Tutor & 26,00 & 74,00 \\
Lecturer & 21,13 & 78,87 \\
Assistant Professor & 21,35 & 78,65 \\
Associate Professor & 30,00 & 70,00 \\
Professor & 60,00 & 40,00 \\
\hline
\end{tabular}

3.2.3. Google Scholar. Google Scholar is a service provided by Google for its users in searching scientific documents in the form of text, Google Scholar presents them in the various publication formats, including journal papers, conference papers, books, patents, and other publications. Google Scholar became one of the largest indexers of online articles in the world. Almost all journals in Indonesia are indexed in Google Scholar. The usefulness of indexation in Google Scholar can help 
lecturers or researchers to disseminate the research results to be cited by other researchers. Google Scholar will help one to identify the most relevant research of all academic research.

Table 4. Knowledge on Google Scholar

\begin{tabular}{ccc}
\hline Functional Position & \multicolumn{2}{c}{ Knowledge on Google Scholar } \\
No $(\%)$ & Yes $(\%)$ \\
\hline Tutor & 16,00 & 84,00 \\
Lecturer & 7,75 & 92,25 \\
Assistant Professor & 6,74 & 93,26 \\
Associate Professor & 0,00 & 100,00 \\
Professor & 0,00 & 100,00 \\
\hline
\end{tabular}

Table 4 shows that almost 90-95\% of the total lecturers have knowledge about Google Scholar. This indicates that lecturers in Indonesia have been familiar with the least indexing database that functionate as a forum to publish the lecturer's scientific work in the field of research and community service. Google Scholar became the basis of lectures publication performance which recorded on SINTA. Therefore, for the $5 \%$ of the lecturers in the table who are not knowledgeable about Google Scholar, they will be encouraged to increase their literacy and insights related to Google Scholar's details. This is because the Google Scholar ownership publication profile is the main requirement to obtain the lecturer performance record through SINTA. Furthermore from 92,09\% who know about publications in Google Scholar, based on empirical frequency about $80 \%$ have publications indexed in Google Scholar.

3.2.4. Scopus. Scopus is the largest abstract database and citation of a scientific publication such as scientific journals, books, and conference proceedings. Scopus contains publications in the form of science, engineering, social sciences, medicine, arts and humanities. At worldwide, Scopus is used by over 3,000 academic, government and corporate institutions and is the primary data source that supporting the Intelligence Research portfolio (Scopus.com). Based on the discussion results in the ResearchGate forum [5], there was a fierce debate about the pros and cons regarding to the question of "Is SCOPUS (Elsevier) a suitable indexing database to evaluate a researcher's career and academic productivity?". Some argue that "Scopus is the best indexing platform among the available databases. Compared to the Web of Science, Scopus covers various journals and conferences. You can find several articles, including non-Elsevier, as soon as they are online as 'in print'. Of course, they have strict indexing rules to maintain quality, which is quite valid. I am not sure about the cost of indexing though." And on the other hand, the cons side with this statement says that (1) the process of its data update is not fast (conference may be waiting until six months before appearing in Scopus), and Elsevier's product may be updated more faster than non-users of Elsevier (e.g. ACM and IEEE); (2) includes only a portion of the scientific literature (e.g. not all IEEE conferences), and (3) Scopus is a commercial database.

Table 5 shows that the number of lecturers who did not know about Scopus is highest among 4 indexing platforms (SINTA, Google Scholar, DOAJ, Scopus) compared in this study at each functional position. Of $59,81 \%$ of lecturers/researchers who know about Scopus and based on empirical frequency there are $76 \%$ who have never done publication in Scopus. It is possible that lecturers / researchers only know about Scopus without ever doing a publication indexed in Scopus. The number of lecturers who did not know about Scopus is closely related to the access to related journals because the journal is paid. The number of Indonesian scientific articles published in Scopus indexed journals has increased significantly and it was the highest at the ASEAN scientific articles (76\%) since 2011 to 2016 (Table 6). 
Table 5. Knowledge on Scopus/Web of Science

\begin{tabular}{ccc}
\hline \multirow{2}{*}{ Functional Position } & \multicolumn{2}{c}{ Knowledge on Scopus } \\
& No $(\%)$ & Yes $(\%)$ \\
\hline Tutor & 42,00 & 58,00 \\
Lecturer & 47,18 & 52,82 \\
Assistant Professor & 32,58 & 67,42 \\
Associate Professor & 30,00 & 70,00 \\
Professor & 20,00 & 80,00 \\
\hline
\end{tabular}

Table 6. Comparison of the number of scientific articles, citations, and $\mathrm{H}$ index of ASEAN countries before the publication obligation policy of scientific articles in international journals for Indonesian doctoral students (2010) and afterwards (2016)

\begin{tabular}{ccccccc}
\hline \multirow{2}{*}{ Country } & \multicolumn{2}{c}{ Documents } & \multicolumn{2}{c}{ Citations } & \multicolumn{2}{c}{ H-index } \\
\cline { 2 - 7 } & 2010 & 2016 & 2010 & 2016 & 2010 & 2016 \\
\hline Malaysia & 15740 & 28546 & 128548 & 19024 & 224 & 224 \\
Singapore & 15590 & 19992 & 321718 & 32504 & 454 & 454 \\
Thailand & 10049 & 14176 & 111214 & 11331 & 269 & 269 \\
Indonesia & 2704 & 11470 & 25644 & 4604 & 175 & 175 \\
Viet Nam & 2163 & 5563 & 28756 & 4970 & 167 & 167 \\
Philippines & 1342 & 2642 & 21430 & 2598 & 189 & 189 \\
Cambodia & 193 & 480 & 4598 & 525 & 86 & 57 \\
Laos & 136 & 377 & 2592 & 552 & 67 & 86 \\
Brunei Darussalam & 124 & 272 & 971 & 485 & 57 & 58 \\
Myanmar & 116 & 256 & 1318 & 338 & 58 & 67 \\
\hline
\end{tabular}

(Source: http://www.scimagojr.com/countryrank.php)

3.2.5. Web of Science. Thomson Reuters is an information company formed through the purchase of Reuters by Thomson Corporation on April 17, 2008. Thomson Reuters shares are listed on the Toronto Stock Exchange (TSX: TRI) and the New York Stock Exchange (NYSE: TRI). Thomson Reuters is headquartered in Midtown Manhattan, New York City, USA. The Wood-bridge Company, a holding company for the Thomson family in Canada holds 53\% of the group's shares, which operates in 100 countries and has more than 55.000 employees. Thomson Reuters became Canada's leading corporate brand on the list of Inter-brand Best Canadian Brands 2010. Web of Science is a Thomson Reuters service product that provides access for academics and scientists to access and to cite the research results more easily.

The knowledge of lecturers and researchers related to the overall publications indexed by Web of Science's, is still poorly understood about it. As many as 56,01\% of lecturers and researchers were still less know about Web of Science, according to the research result.

\subsection{Publication Issues}

Scopus is not clean from predatory journals. Mart, as cited in Savina and Sterligov [6], revealed that the government and academia will be bothered with the fake papers that are claimed to appear in international journals. The development of fake or predatory journals is significantly improved even the predatory journals also present prominently in the 2,79\% of journals indexed in Scopus database by 2015 [6]. Such information is often under-socialized by the government to the scientific community or academics till not a few lecturers who fall into the trap of predatory journals, of course with promise of indexation. 
The ability of lecturers in generating appropriate articles with the indexed journal standards is still minimum and the lack of information on the procedure of the indexed journal become problems experienced by some lecturers / researchers studied. It is true especially for lecturers who are interested only in his or her environment and do not want to explore the world outside. Many lecturers conduct research but only when reporting it into Department of Research and Community Service, they are not brave or lazy to publish their research results. Even though, more of their research can be used directly for a businessmen and stakeholders. In addition, the language barrier is also one of the obstacles of lecturers to be able to publish on reputable international journals indexed in Scopus. Even if the contents of research is worthy to entry at international journals but because the language constraint, the researchers prefer a local journal that is not necessarily indexed and reputable.

The real phenomenon shows that lecturers are too preoccupied with teaching and paradigm of money source which is only obtained from teaching. One of the right strategies is to build the knowledge management and through it the culture of collecting, managing, and sharing publicity knowledge. The simple tactical step of the knowledge management is to make a schedule of workshops about the publications followed by publication accompaniment.

Furthermore, the accepted research report in reputable international journals that have a highquality level might be contributed by adequate funding. Unfortunately, not all researchers in college can access the funding of the study. The research policy still requires competition so more lectures do not qualify than those who qualify. This becomes an imbalance that must be improved, where all lecturers should be able to access the source of research funds. The unevenness of educational facilities and infrastructure in universities is a problem that is still very strong. The most classic example is the laboratory facilities and infrastructures among universities are still showing a gap, as well as reliable laboratory resources. It must be admitted that there is a gap of infrastructure between universities in the region (outside Java) with universities on the Java Island.

The enforcement of rules related to reputable international publication for Associate Professor and Professor functional lecturers is sufficient to have a disastrous impact. It is because the sudden implementation of the policy is accompanied by the "punishment" of terminating the professional lecturers (including professor) allowances. Based on discussions with the researcher/lecturer who participate in this research, there are aspirations that lecturer publication policy to not be linked with the threat of the dismissal of the certification allowance and the honorarium of the professor. The scholarly publications achievement for lecturers who penetrate reputable international journals is the time to be motivated by the provision of additional reward in the form of research funding without selection, so it can motivate researchers and other prospective researchers. Performance of researchers, lecturers and institutions is not only measured by the number of published papers and citations but also measured by the number of unique paper readings.

\section{Discussions}

\section{Is Knowledge / Understanding Sufficient? The Position of This Paper}

The data contained in the four tables (Knowledge about SINTA, DOAJ, Google Scholar, and Scopus) indicated that consecutively the indexing databases known by Indonesian lecturers are 1) SINTA, 2) Google Scholar, 3) DOAJ, and 4) Scopus. SINTA is most widely known when this research was conducted. This is not surprising because of the endorsement by the Ministry of Researcher, Technology and Higher Education of The Republic of Indonesia policy which requires the lecturers to have SINTA account because of the practical implication to the promotion of academic position as well as the acceptance consideration in the future proposal of research grant in the Ministry.

SCOPUS is the least understood indexing database among the four. In this case, Scopus is still perceived as an "alien" by the majority of the lecturers, despite the fact that Scopus contains many useful functions such as publication search serving various boolean operations (so that the retrieval becomes very precise), citation tracking, and author identification. In addition to paid access, this lack 
of understanding may also be contributed by "the experience of contact" with Scopus. This experience in getting published with Scopus journal/proceeding is apparently able to explain the gap between the four tables (Table 2, Table 3, Table 4, Table 5) and Table 6 . It has been known that the number of Indonesian scientific articles indexed in Scopus has increased sharply. The increasing number has been the highest in the ASEAN scientific articles. The numbers even exceeded Thailand, and according to the Ministry's strategic plan would surpass Malaysia.

Based on the empirical data collected through this present study, Scopus is the least understood database. However, the quantity of scientific publications of Indonesians is increasing rapidly in Scopus. How to bridge these two seemingly contradictive realities?

In this Discussion, the author presents a theoretical perspective of the field of psychology, namely the importance of past experience. The authors argue that the disparity between the two realities is highly likely to be due to the experience of "in touch or together with Scopus" is unevenly distributed, both among institutions/universities/research institutes and among lecturers/researchers. This unequal distribution of experience can contribute to the formation of so-called "elitism". The term "elitism" is used to illustrate the possibility that a particular group (both individuals and institutions) contributes to Scopus database with their publication significantly in higher frequency than any other rest group. These "elite groups" are instrumental in accelerating the increasing number of Indonesian publications indexed by Scopus.

Theoretically, these groups are very likely to be the group that has had a debut in the publication of Scopus indexed articles. While the other group, either for one reason or another, has not even debuted, either because of financial, psychological or other structural and/or situational restrictions or barriers.

Based on social psychology studies, one of the most potent predictors found to affect future behavior is past behavior, either through intention [7] or directly without intention [8]. Investigation of these variables is continuously carried out to this day within the framework of the Theory of Planned Behavior (TPB) [9][10]. Ajzen found that the explained variance grew from $41 \%$ to $54 \%$ after adding past / prior behavior into the TPB predictive model of behavior, without mediation of intention; in fact, its predictive power goes beyond the contribution of intentions, attitudes, and other variables in the TPB framework [9]. A number of alternative explanations, such as the high frequency of past behavior, constitute a habituation / routine process that leads to similar subsequent behavioral automation, without meaningful cognitive effort [11].

In that kind context, this paper is written and published. In the dialogues in the Telegram group, the authors of this paper agreed to do a crowd-writing to gain a first experience of obtaining Scopus ID. Related to the mentioned theory, this research contributes to the occurrence of "past behavior" in order to psychologically facilitate lecturers to come back into contact with Scopus in the future. In the psychological term, it is called "efficacy" [12]. In the process of compiling this paper, for example, lecturers are either (consciously) or indirectly (unconsciously) gaining shared learning experience in preparing the Introduction of research. The section containing the state of the art of this paper is the most contributed by lecturers from various scientific backgrounds and institutions.

Therefore, partially the preparation of this paper is actually a good example of a kind of action research. Research is conducted not only to explain phenomena but to make meaningful social changes for both the community and the actors. The writing of this paper would address the inequity of Scopus experience. Thus, knowledge / understanding on indexing databases, according to the results of this present study, might be not sufficient to support the Government's vision to develop the number of publications. It would be unfair if the experience and incentives of publications can only continuously be enjoyed by certain individuals and groups without a meaningful or systematic effort to take care lots of other inexperienced---vis a vis unknowledgable---lecturers/researchers. We could not rely solely on the Government programs and initiatives but as intellectuals need to jointly empower ourselves. Shared or coordinated practices become the unique key words, psychological breakthrough and contribution of this paper to improve the habits and enjoyment of proceeding to give birth to publishable articles indexed in Scopus. That is the position of this crowd-writing paper. 


\section{Conclusion}

On average, 66,5\% of Indonesian lecturers/researchers have known about SINTA, DOAJ, Google Scholar, Scopus, Web of Science. However, based on empirical frequency $76 \%$ of them have never published with journals or proceedings indexed in Scopus.

\section{Acknowledgment}

This article is a development of an article that have been accepted in Joint Workshop of KO2PI 2017 \& ICMSTEA 2016 and then undergone 100\% change with the latest data in the 2017 involving more contributors. Thanks to the committee of $2^{\text {nd }}$ ICMSTEA 2016 and the committee of KO2PI Workshop 2017 to provide opportunities for publication with IOP Publisher.

\section{References}

[1] Kurniasih, N 2016 The implementation of Altmetrics in library as an alternative measurement method for scholarly article impact in social web ecosystem Proceedings of International Conference on Science Mapping and the Development of Science 63-73

[2] Björk, B C and Solomon D 2012 Open access versus subscription journals: a comparison of scientific impact BMC Medicine $\mathbf{1 0} 73$

[3] Chua, S, Qureshi, A M, Krishnan, V et al. 2017. The impact factor of an open access journal does not contribute to an article's citations [version 1; referees: 2 approved] F1000Research 6208

[4] Irawan, D E, Multazam, M T, and Mulyaningsih, I 2017 Status jurnal berbahasa Indonesia di DOAJ https://www.authorea.com/users/87737/articles/160896-status-jurnal-berbahasaindonesia-di-doaj

[5] Ghezzi, A 2012 Is SCOPUS (Elsevier) a suitable indexing database to evaluate a researcher's career and academic productivity? ResearchGate https://www.researchgate.net/post/Is_SCOPUS_Elsevier_a_suitable_indexing_database_to_ evaluate_a_researchers_career_and_academic_productivity.

[6] Sterligov, I and Savina, T 2016 Riding with the metric tide: Predatory journals in SCOPUS Higher Education in Russia and Beyond 1(7) 9-12 https://herb.hse.ru/data/2016/03/02/1125175286/3.pdf

[7] Xu, Y, Li, Y, and Zhang, F 2013 Pedestrians' intention to jaywalk: Automatic or planned? A study based on a dual-process model in China. Accident Analysis \& Prevention 50 811-819

[8] Franklin, K 2013 The best predictor of future behavior is ... past behavior: Does the popular maxim hold water? PsychologyToday https://www.psychologytoday.com/blog/witness/201301/the-best-predictor-future-behavioris-past-behavior

[9] Ajzen, I 2002 Residual effects of past on later behavior: habituation and reasoned action perspectives. Personality and Social Psychology Review 6(2) 107-122

[10] Gadiraju, T 2016 Investigating the determinants of recycling behavior in youth by using Theory of Planned Behavior Unpublished Master's Thesis (Florida, USA: College of Arts and Sciences, University of South Florida)

[11] Ouellette, J A and Wood, W 1998 Habit and intention in everyday life: The multiple processes by which past behavior predicts future behavior Psychological Bulletin 124(1) 54

[12] Abraham, J and Pane, M M 2014 The mediating role of social competition identity management strategy in the predictive relationship between susceptibility to social influence, internet privacy concern, and online political efficacy. In: Linawati, Mahendra, M S, Neuhold, E J, Tjoa, A M, and You, I. (eds) Information and Communication Technology. ICT-EurAsia Lecture Notes in Computer Science, 8407 492-499 (Berlin, Heidelberg: Springer) 